\title{
Recovering from the Effects of Natural Disaster: The Case of Urban Cagayan de Oro, Philippines
}

\author{
Isaias S Sealza ${ }^{1}$ and Lita P Sealza ${ }^{1}$
}

\begin{abstract}
Tropical Storm Washi hit urban Cagayan de Oro, the Philippines, in 2011. It left some 2000 people dead or missing. Thousands of survivor households had to be resettled. Local and international relief groups put up housing structures, health and sanitation facilities, and livelihood opportunities.

This paper posits that the survivor households have recovered their level of living given the inputs from outside groups, and despite cohesion and ethnicity issues commonly attendant to new neighborhoods.

This paper uses data from a survey of 674 respondents in resettlement and village communities. Data show that while the two communities have similar ethnic diversity, the village community shows a statistically significant advantage over the resettlement community in level of living, which suggests that the latter has not recovered yet from the devastation. Cohesion is facilitated by social organizations. Members of social organizations have higher level of living than non-members. And when organizational membership is controlled for, the advantage of the village community in level of living disappears.

It is argued therefore that more efforts from the resettlement communities with support from the local government units, civil society organizations, and humanitarian groups are needed to improve the survivors' living conditions via enhanced campaigns for membership in social organizations.
\end{abstract}

Key Words: Natural Disaster, Cagayan de Oro, Level of Living

\section{Thesis Statement}

When flashflood brought by Tropical Storm Washi hit urban Cagayan de Oro, the Philippines, one midnight in mid-December 2011, formidable floodwater current silently swept away poor and socialized housing communities along river banks and left in its wake some 2000 people dead or missing, some PhP1.3B (US\$29.5M) in damage to property, and thousands of internally displaced persons (IDPs) (Tan, 2011). The survivor households had to be evacuated and eventually resettled. Local and international relief agencies and aid groups hastily put up relief distribution centers, housing structures, health and sanitation facilities, and other contrivances, and subsequently offered skills training and livelihood opportunities, to help the IDPs cope with and sustain life after the catastrophe. There is need for a systematic view to understand a promising entry point for addressing the vulnerability of the survivors in resettlement sites as Cagayan de 
Oro hopes to sustain its being the most competitive city in the country in 2014 (NCC, 2014).

This paper examines the ability of $W$ ashi survivors to bounce back some two and half years after the disaster. It hypothesizes that given inputs from the outside, the resettlement communities have recovered their level of living. It argues that participation in community organization is a vehicle towards recovery.

\section{Review of the Literature and Theoretical Framework}

There can probably be at least three chief challenges that confront IDPs in the resettlements that may have bearing on their ability to recover: the post-traumatic stress disorder (PTSD), cultural discontinuities, and, preexisting vulnerabilities. PTSD is a psychiatric condition commonly resulting in nightmares, flashbacks, impaired functioning, memory issues, and parenting or marital difficulties. It may come after a harrowing experience from natural calamities (Bassam-Bowles, 2014). And since the IDPs may feel that they had no control over events both in the natural and social environment, they may also suffer from the victim syndrome in which they take no responsibility over their actions and also become victimizers (Kets de Vries, 2014).

Natural calamity disrupts community equilibrium. It is life-changing. Experience of cultural discontinuities may occur when people have to interact with new neighbors in a post calamity resettlement. In the old neighborhood, people have somehow made adjustments in their dealings with one another, and majority have blended with one another; in the new neighborhood they suddenly share space with those who probably belong to another ethnic group and whose cultural assumptions (norms and values) they are barely acquainted with. In which case, everyone may feel like a minority. In this kind of neighborhood, there is likely to be very little social capital (trust, cooperation, reciprocity, network, etc.) (Zychowicz, 2009; Martyr, 1985; cf. Ikejiaku, 2012). Along this trend of thought, Ritchie (2012) found that the social impacts of the Exxon Valdez oil spill disaster were "lower levels of trust, disruptions in associations, weakened social connections and networks, altered social discourses, diminished feelings of goodwill, and violations of norms of reciprocity".

Preexisting vulnerability, which refers to the condition of the survivors before the calamity, may also pose a challenge. Often, the more likely victims of disasters are at the bottom of socioeconomic pyramid because they put up their houses in low-cost neighborhoods which commonly lack safety features. In other words, the victims of natural calamities are often the poor who, by their very condition, have very little chance of recovery (Chambers, 1985:116).

Shown in the review of the literature are the constraints that presumably deter the IDPs' recovery, from the perspectives of psychology (PSTD), sociology-anthropology (cultural discontinuities) and economics (vulnerability). But the IDPs are not alone. They have been receiving aid both material and non-material for their survival and sustenance from various groups. Reworded, while the constraints may have been present, but so were the support groups. It becomes imperative therefore to see the level of living of the IDPs vis-à-vis that of the village community residents.

One of the key factors that may facilitate recovery is membership in social organization, a social capital that empowers (Sealza, 2013). It facilitates many things from succor in 
times of crisis, to alliance in matters of advocacies. It is viewed more as conscious cooperation and reciprocity (e.g., Van Vugt and Snyder, 2001) than as simple symbiosis and functional interdependence (e.g., Radcliffe-Brown 1935; Parsons, 1964). These sociocultural patterns imply something that, people feel, makes tangible things in life matter to their daily existence (Newton, 2012); Grootaert et al., 2004; Sealza, 2008).

Looking at the challenges to recovery that the IDPs have been facing and considering, at the same time, the inputs that relief agencies and aid groups have been giving, one is left with the question on whether the survivor households have finally leveled up to the kind of community that it was once like; and, whether membership in social organization plays a key role in the lives of the people.

\section{Methodology}

Data for this paper were part of a survey under the auspices of Cagayan de Oro Archdiocese. They were from a random sample of 674 respondents, broken down into the same sample sizes from the resettlement sites and a barangay (hereafter, village) community, the latter being treated here as control group. An interview schedule (questionnaire) was administered using face-to-face interview. It contained questions on the socio-demographic characteristics of the households, family and health information, membership in organizations, economic characteristics, housing, health and sanitation, and ownership of economic assets.

A level of living index (LLI) was constructed by Principal Component Analysis (PCA) from the family of factor analytic procedures. First, linear correlation analysis was used to filter LLI indicators from a wide assortment of ordinal and interval level variables that appear the strongest in discriminating households with high level of living conditions from those who have low. The level and direction of the correlations coefficients were examined with ownership of cell phone as benchmark indicator, deemed sensitive in separating those who can afford from those who could not. Indicators with high and significant correlation (at the .05 level or better) with the benchmark indicator were included in the PCA procedure. Second, factor analysis was made. After eight runs, an acceptable set of 10 indicators were chosen: socio-demographic (age, education and gender of the household head), health and sanitation (source of drinking water and type of toilet used by the household), housing (house and lot ownership status), and economic (ownership of cell phone, household monthly income, and ownership of refrigerator) (Henry, et al, 2000). .

The values of the communalties from the Component Matrix ranged from 0.36 to 0.67 (recommended value is $>0.30$, going by the Burt-Banks formula). The Kaiser-MeyerOlkin Measure of Sampling Adequacy was 0.60 (recommended value is 0.60 or more) and the Bartlett's Test of Sphericity was 613.101, significant at Chi-Square .001 or better, $\mathrm{df}=45$. The eigen value of the LLI component was 1.964 (recommended value $>1.0)$ (Henry, et al, 2000).

The households were arrayed and ranked according to LLI scores from lowest to highest and terciles were extracted to divide households into three groups. 
Lieberson's index of population diversity was used to measure ethnic mixture, computed as $1.00-\mathrm{S}$, where $\mathrm{S}$ is the sum of squares of the proportion of the community's total population affiliated with each major ethno-linguistic grouping. The index can vary between 0 (where all residents come from the same ethnic group) to a value close to 1.00 . It is designed to measure the "probability that randomly paired member of the population will hold different... affiliations" (Lieberson, 1969).

The difference between resettlement and village communities in terms of LLI was tested with Kolmogorov-Smirnov Z. The association between type of community and membership in organization was measured by the Cramer's $V$ and tested with ChiSquare. The association between membership in organization and LLI converted into terciles was measured by the Cramer's V and tested with Chi-Square. The difference between resettlement and village in term of LLI under the separate categories of membership in organization was tested with Kolmogorov-Smirnov Z. All tests were at the .05 level or better.

\section{Limitations}

This paper represents a secondary analysis of a data set collected mainly to: 1) Determine the living conditions of the residents in the resettlements vis-à-vis those of the residents in the village; and, 2) Examine the adherence of the Roman Catholic faithful to the Church's sacraments in the two communities. Hence, questions to elicit psychological, cultural and preexisting economic (characteristics before the flood) attributes were not included in the data collection instrument.

\section{Results}

Immediately after $W$ ashi, aid agencies and humanitarian groups like the UNICEF, World Food Programme, German Doctors, Catholic Relief Services and many others provided relief goods and services. While in the evacuation centers, government agencies (e.g., welfare, trade and industry, and local government departments, and nongovernment organizations) provided skills training and livelihood assistance programs (Sealza and Abesamis, 2012).

After living for some time in various makeshift evacuation centers, the survivors whose houses totally vanished but who decided to remain in the city were relocated in sites named after sponsors (e.g., Habitat for Humanity, Berjaya, Caritas Village, Gawad Kalinga, Xavier Ecoville, and Lutheran Community).

Cases of PTSD and victim syndrome surfaced in the study by Sealza and Abesamis (2012) conducted right after the disaster. Many were experiencing nightmares, flashback and unable to concentrate in their work. Some young girls became victims of rape, incest, and malicious mischief (Sealza and Santua, 2013). Cultural discontinuities were also observed. There were looting and theft. Some of the resettlement communities were disorganized. Mostly, common norms were not observed. 
As mentioned earlier, there were two communities in this study, resettlement and village. Preexisting vulnerability was evidenced by poverty attendant in both communities. Before the flood, houses of many survivors were built in the city's socialized housing zones and in sandbars along the river under a program in which residents paid one peso $(<1$ US cent) per day to the city government (Pecojon, 2012).

Houses of informal settlers (squatters) in the village community were also flooded because they were close to the river bank. The damage was tolerable so they stayed and rebuilt their homes. There was presumably less cultural discontinuities here than in the resettlements.

The two communities had similar ethnic diversity: the Lieberson's index of ethnic diversity was 0.32 for the village; and, 0.30 for the resettlement.

Some 60 percent of the respondents were members of organizations (either social or church, or both). Prominent among these organizations were: Lay Ministers, Couples for Christ-Gawad Kalinga, Oro Integrated Cooperative, Charismatic Movement, First Community Credit Cooperative, and Construction Workers Association.

Households in the two communities put together were almost equally distributed in the three LLI terciles. But a plurality of households in the resettlement community were concentrated in the lower terciles (First and Second), while a plurality of households in the village community were concentrated in the upper (Third) tercile (Table 1). The village households therefore were more likely to be in the higher LLI ranks than the resettlement households (Kolmogorov-Smirnov $Z=2.080$, sig. at $\alpha .01$ or better, 2tailed).

\begin{tabular}{|l|l|l|l|}
\hline \multicolumn{4}{|l|}{ Table 1. Tercile Distribution Households in Percent } \\
\hline Tercile & Both Communities & Resettlement & Village \\
\hline First & 33.2 & 35.0 & 31.5 \\
\hline Second & 33.4 & 35.6 & 31.2 \\
\hline Third & 33.4 & 29.4 & 37.4 \\
\hline
\end{tabular}

The village also had more members in social organizations than the resettlement $($ Cramer's V $=0.58$; Chi-Square $=229.231$, sig at $\alpha .01, \mathrm{df}=2)$. Members of organizations tended to be in higher LLI rank than non-members (Cramer's V $=0.18$; Chi-Square $=$ 41.313 , sig. at $\alpha .01, \mathrm{df}=4$ ).

When membership in organization is held constant, Table 2 obtains.

Table 2. Type of Community and Level of Living Under Separate Categories of Membership in Organization

\begin{tabular}{|l|l|l|}
\hline $\begin{array}{l}\text { Type of community and level living under the } \\
\text { category: }\end{array}$ & Kolmogorov-Smirnov Z & $\begin{array}{l}\text { Asymp. Sig. (2- } \\
\text { tailed) }\end{array}$ \\
\hline No membership & 1.670 & .01 \\
\hline Member of either church or social organization & 1.274 & .08 \\
\hline Member of both church and social organization & 1.042 & .23 \\
\hline
\end{tabular}


The village dwellers were likely to be in higher LLI rank than resettlement dwellers if they were not members of any organization (Kolmogorov-Smirnov $Z=1.670$, sig. at $\alpha .01,2$-tailed). For members of voluntary organization, LLI scores in both areas were not significantly different at the .05 level, 2-tailed test (Table 2).

\section{Conclusion and Implication}

It may be recalled that this paper seeks to examine the ability of the $W$ ashi survivors to bounce back after the disaster. It hypothesizes that given inputs from the outside, the resettlement communities have recovered their level of living. It argues that participation in community organization is a vehicle towards recovery.

The living conditions of the resettlement IDPs and the villagers might have been very similar before the flood. It appeared that the dwellers in resettlement communities were able to catch up with the village dwellers in the level of living if the survivors were members of social organizations (e.g., cooperatives and church-related organizations). This might have been because programs introduced from the outside have been built upon structures that demand adherence to rules and norms in social capital formation (e.g., cooperation, trust, networking and social cohesion); and, to the set of laws being enforced by formal organizations like the cooperatives and labor organizations.

These social organizations may have afforded (1) "bonding" social capital based on cooperation among people who have "primary" relationships, as in church-related groups and (2) "bridging" social capital based on "secondary" relationships, as in cooperatives and labor unions. These may have provided reciprocal services that extended from personal bonding at one end to formal bridging at the other end (Patrinos and Skoufias, 2007).

Membership in organizations may have also enhanced the survivors' capability to recover from their psycho-emotional trauma and to regain functionality. It may also have helped them recognize community norms, toe the line and build up social capital; and, in the same token, helped them overcome economic vulnerabilities.

It is argued therefore that more efforts from the resettlement communities with support from the local government units, civil society organizations, and humanitarian groups are needed to improve the survivors' living conditions via enhanced campaigns for membership in social organizations.

\section{References}

Bassam-Bowles, C. (2014) Post Traumatic Stress Disorder Due to Natural Disasters. Retrieved June 19, 2014 from http: / / www.harleytherapy.co.uk/counselling/post-traumatic-stress-disorder-as-a-result-of-natural-disasters.htm Chambers, R. (1985) Rural Development Putting the Last First. New York: Longman Group Limited. 


\section{Grootaert, C., Narayan, D., Jones, V. N., \& Woolcock, M (2004). Measuring Social Capital. Washington, D.C: IBRD, World Bank.}

Henry, C., Sharma, M., Lapenu, C., and Zeller, M. (2000) Assessing the Relative Poverty of Microfinance Clients. Washington D.C.: International Food Policy Research Institute.

Ikejiaku, B-V. (2012) Poverty-Conflict Nexus: The Contentious Issue Revisited. European Journal of Sustainable Development (2012), 1, 2, 127-150.

Kets de Vries, M.F.R. (2014) Are You a Victim of the Victim Syndrome? A Working Paper Retrieved on June 19, 2014 from http://www.insead.edu/facultyresearch/research/doc.cfm?did=50114

Lieberson, S. (1969) Measuring Population Diversity. American Sociological Review 34(6): 850-862).

Martyr, J.W. (1985) Cultural Discontinuties and the Transfer of Management Philosophies and Practices. Retrieved June 18, 2014 from http://bura.brunel.ac.uk/handle/2438/5427

NCC (2014) National Competitiveness Council Releases Results of First Cities and Municipalities. Retrieved June 24, 2014 from www.competitive.org.ph

Newton K. (2012) Trust, social capital, civil society, and democracy. Retrieved Oct 14, 2012 from knewton@socsci.soton.ac.uk

Parsons, T. (1964) The Social System. New York: Free Press.

Patrinos, H.A \& Skoufias, E. (2007) Economic opportunities for indigenous peoples in Latin America. (Conference Edition). http://siteresources.worldbank.org/INTLAC/Resources/Synthesis_ConferenceEdition_FINAL.pdf

Pecojon, P.H. (2012) Death, destruction followed Sendong in "unprepared" Oro. Retrieved May 3, 2012 from http://news.pecojon.ph/?p=1597

Radcliffe-Brown, A.R. (1935) On the Concept of Functionalism in the Social Sciences. American Anthropologist, 37

Ritchie, L.A. (2012) Individual Stress, Collective Trauma, and Social Capital in the Wake of the Exxon Valdez Oil Spill. Sociological Inquiry, 82 (2).

Sealza, I.S. (2013) Women Empowerment Through Learning and Livelihood Project. Ch 8 in Singh, Gonzalez and Thomson, Eds. Millennium Development Goals and Community Initiatives in the Asia Pacific. New Delhi: Springer.

Sealza, I.S. \& Santua, M.E. (2013) Prevalence of Failed Pregnancy and Case Narratives

in Cagayan de Oro City. Unpublished research report the Department of Health-Center for Health Development in Northern Mindanao (DOH-CHDNM). Cagayan de Oro City: Research Institute for Mindanao Culture, Xavier University.

Sealza, I.S. and Abesamis, L.J.A. (2012) UNICEF Humanitarian Assistance for Sendong Survivors in the Cities of Cagayan de Oro and Iligan. Unpublished research report submitted to the UNICEF. Cagayan de Oro City: Xavier University.

Sealza I.S. (2008) Disparity within poverty, and social capital among Manobo indigenous

peoples. Paper presented at the international conference on Philippine Studies, Panel 7E. Manila.

Tan, K.J. (2011). Sendong' deadliest cyclone in 12 years with over 1000 dead. GMA News. Retrieved on March 20, 2012 from http://www.gmanetwork.com/news/story/242343/news/nation/sendongdeadliest-cyclone-in-12-years-with-over-1000-dead

Van Vugt V, Snyder, M. (2001) Cooperation in society: Fostering community action and civic participation. American Behavioral Scientist, 45:765-768. Retrieved June 24, 2014 from http://www.professormarkvanvugt.com/files/CooperationinSociety-

AmericanBehavioralScientist-2001.pdf

Zychowicz, M. (2009) Cultural Discontinuities: Insights Into Latino Educational Values in Latino Migrant Community in the U.S. Submitted to the Graduate College of Bowling Green State University in partial fulfillment for the degree of Master of Arts. Retrieved June 18, 2014 from https://etd.ohiolink.edu/rws etd/document/get/bgsu1257179655/inline 
